\title{
Future Scenarios and Environmental Education
}

\section{Helen Kopnina}

To cite this article: Helen Kopnina (2014) Future Scenarios and Environmental Education, The Journal of Environmental Education, 45:4, 217-231, DOI: 10.1080/00958964.2014.941783

To link to this article: http://dx.doi.org/10.1080/00958964.2014.941783

$$
\text { 冓 Published online: } 19 \text { Aug } 2014 .
$$

$\sqrt{6}$ Submit your article to this journal $\square$

$$
\text { Џ Article views: } 486
$$

\section{a}

View related articles 주

View Crossmark data ¿

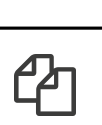

Citing articles: 2 View citing articles 


\title{
THEORETICAL RESESARCH
}

\section{Future Scenarios and Environmental Education}

\author{
Helen Kopnina \\ University of Amsterdam, Amsterdam, The Netherlands
}

\begin{abstract}
This article explores a number of questions about visions of the future and their implications for environmental education (EE). If the future were known, what kind of actions would be needed to maintain the positive aspects and reverse the negative ones? How could these actions be translated into the aims of EE? Three future scenarios are discussed: the limits to growth (the great tragedy and demise); sustainable development and ecological modernization (hope and innovation); and the Anthropocene park. These scenarios are linked to corresponding EE/ESD approaches and instrumentalism in education is argued as a morally justifiable goal. Finally, education for deep ecology is advocated in order to address the ethical implications of the last scenario.
\end{abstract}

Keywords anthropocene, education for sustainable development (ESD), environmental education, future scenarios, sustainable development

\section{INTRODUCTION}

The novel The Master and Margarita by Mikhail Bulgakov (1891-1940), is woven around a visit to Moscow by the Devil, Woland, who introduces himself as a "foreign professor of black magic." The Devil's performance exposes the greed and bourgeois behavior of the ordinary Soviet citizens. The Devil's visit starts at the center of the literary elite's "Moscow Association of Writers." The "foreign professor" tries to convince the unbelieving director of the literary association, Mikhail Berlioz, and his companion, militantly atheistic poet Ivan Bezdomny, of the inescapable trap of their destiny and Berlioz's imminent mortality. Despite Berlioz's efforts to brush off the prophecy of his death, this "foreign professor" accurately predicts the director's demise under the tram some minutes later, and challenges Ivan's conviction that neither devils nor destiny exist (Bulgakov, 1996, pp. 10-12). Ivan, who has followed the entire conversation and witnessed this "tragic accident" is now convinced that his own unenviable destiny, predicted

Correspondence should be sent to Helen Kopnina, Amsterdam Institute for Advanced Labour Studies, University of Amsterdam, Plantage Muidergracht 12, Amsterdam 1018TV, The Netherlands. E-mail: alenka1973@yahoo.com 
by the Devil, might also unravel, and attempts to take steps to prevent his own demise, as well as to reveal the truth to the skeptical authorities.

Imagine a variation on this plot. Imagine that one is told that climate change is caused by the anthropogenic activities, and that it is likely to cause conditions leading to floods, draughts, and other disasters. One may or may not believe this, partly due to one's (limited) scientific knowledge, partly due to one's indifference or apathy. Imagine that something related to the predicted conditions affects the weather close to home and one's friend perishes in a flood in the middle of the city. One may consider brushing off the tragic happening as a freak accident, or one may be willing to recognize "the bigger picture" and accept the inconvenient truth. One may take steps toward prevention of a similar accident, trying to convince the authorities that something needs to be done to curb carbon emissions. Alternatively, one may sink into indifference and apathy until the next flood sweeps over his city.

This, in a nutshell, is the "plot" of this article that aims to ponder the questions related to the future(s) we imagine, the possibilities of these future scenarios coming true, and consequences for our action as educational theorists and practitioners.

\section{EDUCATING IN PURSUIT OF SUSTAINABILITY}

The Club of Rome, a global think tank founded in 1968 to address a variety of international political issues, set out to answer this question: What would happen if the world's population and industry continued to grow rapidly? Could growth continue indefinitely or would we start to hit limits at some point? Addressing the "limits to growth" (Meadows, Meadows, Randers, \& Behrens, 1972), and fostering a "steady state economy" (Daly, 1991) required drastic measures, including curbing human population and stringent environmental protection. Rejecting neoMalthusian pessimism, the concept of sustainable development has germinated through Our Common Future, the report of the World Commission on Environment and Development (WCED, 1987). In the consequent decades, environmental education (EE) and education for sustainable development (ESD) literature developed rich debates about the objectives of education in general and EE and ESD in particular.

A number of EE/ESD scholars have pointed out the tension between the sense of urgency emerging from a deep concern about environmental issues and the conviction that it is wrong to persuade people to adopt expert-determined ways of thinking and acting (Kronlid \& Öhman, 2013; Wals, 2010). Jickling (1994) questioned the aim of education for sustainable development in his article "Why I Don't Want My Children to Be Educated for Sustainable Development." Jickling argued that since both "environmental problems" and "sustainable development" are contested concepts, the prescription of a particular outlook will limit the development of students' autonomous thinking. Instead, he called for developing students' critical thinking in a way that transcends any immediate instrumental goals. Part of the argument for this perspective is the fear of indoctrination, either by corporate and political elites, or by "environmentalists" advocating specific sustainability solutions.

In reflecting upon the case of the Yukon's government's plan to shoot wolves and his own involvement as a schoolteacher in a local community, Jickling (2005b) argued again that environmental advocacy in education needed to be approached with caution. He felt that advocating his self-proclaimed deep ecology perspective (pro-wolf position) would be "neither practically viable 
nor educationally justifiable" (2005b, p. 92). This concern was partially explained by the fact that Jickling faced a class of pupils with different values, some of whom had parents who supported a wolf kill program. However, another source of doubt was his concern with the question "How can we ensure that educational programs provide a sufficient breadth of alternatives for learners to ponder and use to construct meaning in the face of important decisions?" (Jickling, 2005b, p. 93). ${ }^{1}$

Perhaps the most explicit mention of the caution against environmentalist advocacy is made by Wals and Jickling (2002, p. 225):

\footnotetext{
If we juxtapose more instrumental views of "education for sustainability" with more emancipatory views of "education for sustainability" we can imagine, on the one hand, an "eco-totalitarian" regime that through law and order, rewards and punishment, and conditioning of behavior can create a society that is quite sustainable according to some more ecological criteria. Of course, we can wonder whether the people living within such an "eco-totalitarian" regime are happy or whether their regime is just, but they do live "sustainably" and so will their children.
}

Indoctrination, coercion and anti-democratic tendencies were "painted" into this critique, with the well-placed warning against accepting the mainstream, top-down vision of sustainable development (Jickling, 2005b). As a cautionary note against advocacy positions it was argued that education should be concerned with empowering people to think for themselves (Jickling 2005a, 2009; Jickling \& Wals, 2008; Öhman \& Östman, 2008). ${ }^{2}$ While maintaining the position that the purpose of education is not to contribute to solving sustainability problems by promoting particular outcomes, the aim should be the "empowerment" of active, critical and independent citizens (e.g., Mogensen \& Schnack, 2010). This brings his position closer to the socially critical scholars who argue for engaging students in critically appraising environmental situations.

\section{FUTURES VISIONING}

Another question can be added to this practical and moral dilemma of educating for autonomous thinking or for solving sustainability issues. If the future was known, or at least anticipated, and if the wolves were to be driven out of most places aside from patches of wildlife reservoirs and zoos, would this future vision make a difference in terms of the ethical and practical value of environmental education?

Future scenarios and visioning have proved useful for environmental education because they make participants feel responsible and empowered to take action to reach their vision for a better community by raising their awareness of environmental issues (Velarde, Rao, Evans, Vandenbosch, \& Prieto, 2007). These scenarios help to both flesh out the aim and underlying ethics of environmental education, as well as suggest practical and pedagogical tools by which the aim is to be achieved.

This "open" aim of teaching students to think for themselves to ensure that they are adequately prepared to play an active role in democratic processes was in turn criticized. Michael Bonnett (2013a) asks a crucial question concerning the topic of environmental problems that education aims to address: What is the real catastrophe? One of the reasons why such a question is difficult to answer, he suggests, is the inability of EE/ESD scholars and practitioners to agree on what the catastrophe means, and how it might play out in the future. Advocating plural, democratic, open 
approaches, it was argued, does not address the urgency of real-world problems that arise as a result of continuing exploitation of the environment (Bonnett, 2013a, 2013b; Fien, 2000).

In line with Orr (1994), Fien (2000) argues that all education is necessarily political and there is a need for recognition of the difference between educating students to be active citizens for a specific cause or without a cause, as a general competence. The focus on real world problems unites Bonnett, Fien, and Jickling in their critique, but it is the pedagogical process on which they fundamentally disagree.

The authors supporting pluralistic approaches do not necessarily disagree about the urgency of solving environmental problems; the difference in these positions lies in the solving strategy. One is more inclusive of different pedagogical approaches and hopeful that the real-world problems can be indeed addressed through teaching students to think for themselves; the other argues that only a critical pedagogy approach is consistent with the aim of solving these real-world problems. As a helpful reviewer of this article has suggested, both schools of thought are instrumental and advocate students solving the problems with teacher guidance.

Presenting environmental problems as the issue of depletion of natural resources implies that protection of environment is only important in as far as it serves human interests, and that students are not taught to recognize the intrinsic value of nature (Bowers, 2002; Kopnina 2013a; Orr, 1994). As an alternative, the recognition of planetary sustainability as a vital and necessary critical concern was first put forward by scholars with a critical theory orientation (e.g., Huckle, 1993, 1999; Robottom, 1987) and the "socially critical" and "post-critical" perspectives (Payne, 2010). In his work on post-critical inquiry, Paul Hart (2005) proposes "methodological expansion," via interpretive inquiry in order to frame the embodied, embedded, and ecologically "lived experiences," providing opportunities for curriculum theorists to "reframe" aspects of the socially critical perspective in order to inform new imaginaries in EE. Kahn (2010) shares concerns about the capitalist orthodoxy of consumerism, careerism, and corporate profiteering, but also joins Orr (1994) and Bowers (2002) in urging educators and citizens to realize the importance of placing ecological concern and care at the forefront of their pedagogical endeavors. The resulting pedagogy proposed teaching students how to solve real-world problems in the way that is consistent with realistic evaluation of the future prospects of our planet.

The very process of learning depends on a general belief or outlook on life, such as-to return to Bulgakov's novel — whether the Devil exists, and what can be-or indeed should be-done to prevent what one sees as a future threat. We shall discuss three of the broadly sketched "future scenarios": The Limits to Growth (the great threat); Sustainable Development and Ecological Modernization (hope and innovation); and the Anthropocene park (tragedy of non-humans). We shall link these scenarios to corresponding EE/ESD approaches, and develop the argument for supporting deep ecology, consistent with the most likely scenario.

\section{THE LIMITS TO GROWTH (THE GREAT TRAGEDY AND DEMISE)}

The Limits to Growth report (Meadows et al., 1972) published the results of computer simulations of the global economy. The simulation recorded five parameters (population, agricultural production, natural resources, industrial production, and pollution) projected the computer-generated values of these parameters for the period from 1970 to 2100 . For a wide range of input assumptions, the projections predicted that sustainability of life on the finite planet may not be an 
option. A well-respected group of systems analysts appealed for urgent measures for addressing population growth and unsustainable consumption. Hall and Day (2009) have re-examined some of the data that led to the discrediting of the Limits to Growth, demonstrating that both resource use and costs have only risen, and are no longer being mitigated by market forces. Wijkman and Rockström (2012) demonstrate that despite growing scientific consensus on major environmental threats, societies are largely continuing with business as usual, at best attempting to tinker at the margins of the problems. This calls for a radically different type of education, teaching students to tackle the uncomfortable issues regarding population and economic growth, critically addressing the very tenants of industrial neo-liberal democracies (Bonnett, 2013a; Fien, 2000; Gough, 2006, Huckle, 2008; Kopnina 2012a, 2013b, 2013c).

Translated into Bulgakov's novel, this approach would call for Ivan to accept the inevitability of destiny and by implication his own mortality and simultaneously attempt to stop it - by convincing the authorities that the Devil exists, by trying to warn his own literary colleagues of imminent danger, and trying to courageously steer his own life to veer off from its inevitable trap of misery. This is more or less what actually happened in the novel, but not in educational practice.

\section{SUSTAINABLE DEVELOPMENT AND ECOLOGICAL MODERNIZATION (HOPE AND INNOVATION)}

One proposed solution to preserving the environment was commodification of nature, or putting a price on "ecosystem services" to ensure the provision of natural resources for future generations. Researchers have shown that given present socio-economic conditions, putting a price on nature may be the only way to guarantee its preservation (e.g., Armstrong, Foley, Tinch, \& van den Hove, 2012; Farley, 2012).

This optimism is grounded in a belief in human ingenuity, solving problems by technological advancement. Ecological modernization theory (e.g., Mol \& Sonnenfeld, 2000) states that enlightened self-interest, economy, and ecology can be favorably combined and that productive use of natural resources can be a source of future growth and development.

In the case of EE/ESD, this relatively optimistic scenario has led scholars to consider two types of instrumentality. One type intended to lead to achieving certain aims of sustainable development and ecological modernization. Another deconstructs "sustainability" as an open and potentially participatory concept. The former view implied that education for sustainability and ecological modernization would amount to equipping students with sustainability competencies (competence-based learning and assessment regarding real-life issues), skills and knowledge (e.g., Wals, 2012; Wesselink \& Wals, 2011).

Wals (2012, p. 84) has noted that "colleges and universities around the world are starting to make more systemic changes towards sustainability amidst educational reforms towards efficiency, accountability, privatization, management and control." This spelled the need to educate citizens knowledgeable in environmental management, technical and scientific systems.

The latter view propagated values congruent with open, democratic, participatory approaches that recognized plurality of perspectives (e.g., Læssøe \& Öhman 2010; Öhman \& Östman 2008). Thus, EE/ESD has morphed into educating citizenry in pluralistic approaches and broad thinking without actual specialized goals. This view is supported by "pragmatist" environmental ethics 
critical of what its proponents saw as simplistic division between anthropocentric and ecocentric approaches (e.g., Katz, 1998; Light, 1996; Norton, 1995).

Yet, in regard to the former view, critics argue that ecological modernization does nothing to alter the impulses within the capitalist economic mode of production that inevitably lead to environmental degradation (Foster, 2002, 2012; York \& Rosa, 2003). Bonnett (2013b), Cherniak (2012), and Stables (2013) argue that techno-scientific knowledge alone is inadequate-even antipathetic - to a proper understanding of the natural environment and its role in the debate that supports the mythical "magic bullet" of technical fixes.

In regard to the latter view, the question arises as to the purposes or goals to which this autonomous student thinking should be applied. It is not clear whether the aims are to be determined by each individual student and if so, then how is social transformation to be brought about? If all learning outcomes are considered equally valid as long as they have emerged from a pluralistic process, this might lead to an "anything goes" relativism (Wals, 2010) and abandonment of the quest for sustainability (Cherniak, 2012).

Translated into Bulgakov's novel, this approach would call for the stunned companion of the tragically deceased Berlioz to accept that destiny may be a possibility, but (a) it can be controlled or managed; and/or (b) destiny is an illusion and rather than accepting its inevitability, we can learn to live with different possibilities of our (perhaps not so imminent) end; and (c) we can actually work together with the Devil.

\section{THE ANTHROPOCENE PARK}

Returning to the first scenario of Limits to Growth, there are at least two reasons why we should educate students to protect the environment: first, for our own human sake (as we need natural resources); and second, for the sake of nature itself. In regard to the first point, while publications about high interdependency of all species (e.g., Kumar \& Kumar, 2008), empirical evidence of mass extinctions shows that a purely economic approach to biodiversity conservation is inadequate (Redford \& Adams, 2009). Empirical evidence also shows that humans can be largely sustained by monocultures, implying that some biodiversity is dispensable, because no negative side effects for people ensue when they are gone (Kareiva, Lalasz, \& Marvier, 2011; Marris, 2011). In his book Do We Need Pandas? The Uncomfortable Truth About Biodiversity, Thompson (2010) suggests that we should stop worrying about functionally useless species, and should concentrate on those species that future human generations really need. This view overlaps with the second scenario, which would allow for some elements of nature to be preserved for future human generations. Propagating the view of eco-centric conviction that non-human lives are important is "rooted in misanthropy and distrust of humans." Marvier $(2014$, p. 1) argues that conservationists should respect different pluralistic perspectives and motivations:

People are motivated to protect nature for a wide variety of reasons. Some want to sit in meditative repose in the cathedral-like silence of a forest. Others feel deeply that all creatures have an equivalent moral claim to existence. And some want to shoot animals and put their heads on the wall. ... Why are people who love the diversity of plants and animals and habitats so afraid of a diversity of approaches that would result in compromise rather than strict policies? 
Cafaro and Primack (2014) and Miller, Soule, and Terborgh (2014) have voiced their concern that plural approaches to nature conservation will lead to abandonment of protection of species not instrumental to human well-being. Crist (2012, p. 145) articulates this future vision:

In contrast with many of my colleagues, I do not necessarily foresee a world that collapses by undermining its own life-support systems. It may instead turn into a world that is molded and propped by the strengths advanced industrial civilization has at its disposal: the rational-instrumental means of technical management, heightened efficiency, and technological breakthrough. It is possible that by such means a viable "civilization" might be established upon a thoroughly denatured planet. What is deeply repugnant about such a civilization is not its potential for self-annihilation, but its totalitarian conversion of the natural world into a domain of resources to serve a human supremacist way of life, and the consequent destruction of all the intrinsic wealth of its natural places, beings, and elements.

Is this scenario acceptable? Crist's (2012, p. 145) vision attacks what some academics have lost out of sight — the case of utter injustice embodied in human supremacy that runs through the first two future scenarios:

Human supremacy has ensconced widespread indifference toward the plight of nonhumans and their homes; it ignores, and keeps itself ignorant of, the question of their reproductive rights, as individuals and as species. The dominant culture thus seems unable to grasp the moral evil of erasing wild Nature just to accommodate more and more of people to live, all at once, on a planet occupied as a resource satellite.

Empirically speaking, we may find this scenario closer to what we observe rather than "doom and gloom" or "bright future for all" varieties. This scenario is disturbing not because of the inevitable destiny of Malthusian proportions, but because it presents what philosopher Zizek (2010) would call "the soft apocalypse" in which intrinsic wealth of natural places is lost. We may thus ask ourselves: is this the future we want our children (let along offspring of other species) to live in? Rather than talking about imminent disaster (scenario 1), or in line with hope and innovation (scenario 2), this third scenario calls for ethical considerations in regard to nature.

\section{WHY IS PLURALISM “NOT GOOD”?}

To return to the question about why pluralism is not "good," the opponents of the Anthropocene park scenario reply that not all ethical perspectives will guarantee protection of non-humans. Not all pluralistic frameworks embrace the moral injustice of extinction (Cafaro \& Primack, 2014; Miller, 2014). Also, this pluralism reflects the double-standard that the purported pluralist thinkers apply in the case of humans and non-humans (Kopnina, 2012b, 2013a, 2014). Most polite academics now will protest against the moral evil of slavery, racism, sexism, and genocide. Very few academics are willing to argue in favor of ecumenical perspectives when it comes to different forms of social segregation and discrimination—not to mention murder—of a human. Death of a nonhuman, for example as roadkill, is often relegated to the realm of nuisance or collateral damage (Desmond, 2013).

Bonnett (2004) has argued how the arrogant instrumentality in relationship to nature hollows out our relationship with the fullness of other beings. Our senses are subverted such that sight is turned into essential blindness (always looking past things themselves to how they might serve 
us) and touch into essential manipulation. While the "resource" approach might serve the aims of the Limits to Growth and sustainable development adequately, it falls short of addressing the very essential ethical issue.

Returning to Marvier (2014) who argues for plurality of approaches to conservation, we may only wonder how educationists would react to the pluralism in relation to people. To rephrase the Marvier's quote: "People are motivated to protect slaves for a wide variety of reasons. Some want to sit in meditative repose in the cotton blossoms on the plantations. Others feel deeply that all creatures have an equivalent moral claim to freedom. And some want to shoot slaves and put their heads on the wall. ... Why are people who love the diversity of people and cultures so afraid of a diversity of approaches that would result in compromise rather than strict slave protection policies? It is not likely that pluralism-supporting academics will subscribe to the openness of approaches in this case.

In the context when human "happiness" is opposed to the feared "eco-totalitarian regime" (Wals \& Jickling 2002) the consideration of "happiness" (or, for that matter, survival) of nonhumans is not considered. Even the positions encompassing (among others) eco-centrism and deep ecology, such as critical pedagogy, post-structural and post-critical theory, or post-critical framings and the "new imaginaries in EE" do not go far enough. The catastrophe of the ultimate subordination of nature to human interests (Bonnett, 2013a; Kopnina, 2014) and the daily slaughter of animals for human consumption and experimentation (Crist, 2012; Kopnina, 2012b) are seen at best as one of many challenges for education. Without moral guidance in education, the catastrophe of causing the loss of the Earth's biodiversity and subordination of nonhumans is likely to continue. This position of denial of catastrophe for nonhumans constitutes what we may call the Anthropocene park.

At the end of the Bulgakov novel, Berlioz (or rather his severed head) temporarily is roused to consciousness at the Devil's Ball of the Dead, only to be told by the satanic comedians that what happens to one after death is determined by their own belief. Berlioz, being a convinced atheist in life, is thus "allowed" to disintegrate into dust rather than enjoy the endless possibilities he failed to consider.

Are we, educational theorists and practitioners, close to assuming that there is nothing of the fate of this world that we can change through education? Would the deadly silence of parking lots' pavement and burning-or occasionally flooded-places where former cultural and biological diversity was allowed to bloom in fact become our destiny, as a way of self-fulfilling prophecy? Or is there still hope to be found in-among other things-education for (truly!) our common future?

I would thus like to return to the position associated with the deep ecology movement. While the scope of this article does not allow for more detailed elaboration, it needs to be noted that the deep ecology position is differentiated from the positions of social ecology, eco-feminism, and other environmental ethics theories even though they too have internal variations. Although variations on the position are articulated by different authors, generally it is reasonable to assume that this position of deep ecology postulates that non-human nature as a whole, or individual non-human entities, have intrinsic value beyond their instrumental value for human well-being. It is also assumed that humans are part of nature but do not have exclusive "rights" that raise them above other planet's inhabitants (e.g., Callicott, 1989; Goodpaster, 1978; Merchant, 1992; Naess, 1973; Rolston, 1985; Taylor, 1986). 


\section{EDUCATION FOR DEEP ECOLOGY}

In terms of education, this position is often associated with education for deep ecology (Bonnett, 2013b; Drengson, 1991; LaChapelle, 1991; Van Matre, 1978). Proponents of deep ecology often recognize alternative ecocentric values arguably present in "traditional" societies (e.g., Baines \& Zarger, 2012; Lotz-Sisitka, 2004). Resituating EE and ESD within this alternative paradigm of abundant earth can act as a counter to the potentially overweening power of human superiority of the neo-liberal industrial age, which can be identified as a prime source of our current environmental predicament (Bonnett, 2013b). Such renewal of EE and ESD can help to bring to the foreground the idea of teaching and learning through a non-anthropocentric frame of mind that is open to the transcendent other, and thus to the fullness of what Bonnett (2013b, p. 268) calls "truly environing."

Pedagogically, a return to education associated with significant life experiences, such as hiking in wilderness areas as a youth (e.g., LaChapelle, 1991; Reed \& Rothenberg, 1993; Wells \& Lekies, 2006); as well as strategically significant education (e.g., Chawla \& Cushing, 2007; Kenis \& Mathijs, 2012), action competence (e.g., Jensen \& Schnack, 1997), social learning (e.g., Wals, 2010), and variations and combinations of those and many other pedagogical approaches developed in the past 40 years. Some of these pedagogical approaches have been disputed-for example, the belief that experiencing environment first hand is an essential component of engaging people in conservation has been disputed by arguments that these education efforts have been informed by behaviorist socio-psychology models that assumed a linear causality between education experience and pro-environmental behavior (Blewitt \& Tilbury, 2013). Rather, the critics have argued that people's environmental behaviors are too complex and contextually dependent to be captured by a simple casual model (Wals, 2010).

While the pedagogical tools may be disputed, the choices are already in place. The ethical case for employing them for certain ends-in this case, a deep ecology perspective-needs to be articulated in the way they have been in cases that are now taken to be morally granted, such as the need to promote gender and racial equality, and care about poor people in distant countries. This switch to considering moral responsibility toward other species still needs to be made-both by the general public and by many/most education professionals.

It is the willingness to return to the roots-the earlier concerns with the limits to growth from the first scenario, and the pro-active means of achieving realistic targets from the second scenario-that are needed. Contemplating our possible destiny may move us toward returning to education for something that we value, as a counterbalance to the amorphous "pluralism" supported in a wave of publications. Students cannot be expected to "think for themselves" if future scenarios are not critically examined, and if the "catastrophe" is not identified, but masked by a multitude of (largely anthropocentric) interpretations of what the problem is. To express the author's point plainly - while realizing that this position is morally subjective (but so are all moral positions, including our present-day assumptions that slavery is bad, or that racial equality is good, or that women should be equal to men) — the third scenario is morally abhorrent. While in pluralist democratic societies (and polite academic circles) we teach our children to respect each other and let all the flowers bloom—-meaning all opinions—quite instrumentally!), why not teach them to respect other planetary citizens? I would also argue that it is quite clear what unsustainability is, because, like Ivan, most of us have seen "the Devil." Thus, warning the others through education, even at the risk of being labelled as alarmist or simply "unscientific" is well worth trying. 
If (at least some) environmental education practitioners agree with this position, they need to employ the ultimate instrumental approach. This "radical" approach could involve moral education, as well as affirmative action employing environmental advocates in order to give "voice" to non-human species.

Returning to Jickling's (2005b) observation that the relationship between education and advocacy remains a difficult one and his own experience with environmental advocacy for the wolves, educators indeed are given responsibilities for both guiding learning and engaging with radical questions on critical issues, as well as providing students with competencies to engage with such issues. Jickling asserts that advocating for the wolves can lead to advocacy of one chosen position, leading to a "mild form of coercion" (2005b, p. 108). A vibrant democracy, he continues, depends on participation. However, we may note that in the case of non-humans, this participation-other than through human advocates-will never be possible. Unlike the case of disadvantaged human groups, non-humans will never speak for themselves. Advocacy through eco-centric human educators might be the only form of defense these planetary inhabitants have against the threat of mass consumption (e.g., farm animals), abuse (e.g., medical experimentation), and extinction.

Let me conclude with the Russian forum of the Portal of Natural Sciences participants discussing The Master and Margarita in order to comment on these questions. "In The Master and Margarita"—one blogger Srarozhyl commented- "Berlioz asserts that there is no God, and that Man rules over everything in the world. Woland [The Devil] asserts, however, that in order to rule, one needs to have a plan, or a vision, for a long time ahead, at least for one thousand years. But a Man is mortal, and what's more, unexpectedly moral, and thus cannot really rule. Does it mean, there is a God? Or not? What do citizen-atheists think about it?" Response by Omega: Grandma said it both ways [literal translation, meaning "It's ambiguous"] (The Portal of Natural Sciences, 2011).

The question of acting without knowing the future remains ambiguous. But we, as humans, as academics and educators, have the propensity to try anyway. Just as Ivan tries to warn the world about the Evil, if we see anthropogenically caused extinction as Evil, we should act to stop it. It will not be stopped by recitations of the limits of the Earth's resource capacity or by conventional rhetoric of combining social, economic, and ecological interests. "Saving the world," or at least some of its planetary citizens, is something we should be courageous enough to do, in front of the class within the closed walls, or out in nature, or whatever pedagogical tools afford us the possibility to do so, if we have a vision of the future and if we believe that we can influence it in any meaningful way, that is.

\section{CONCLUSION}

I have sketched three possible "future scenarios" in relation to environment, sustainability, and education. The first two scenarios describe ethical situations that are familiar and acceptable for most theorists and practitioners of environmental education-namely, the moral imperative to provide food for growing human population, to equally distribute the resources among "developed" and "developing" nations, to combat poverty, racism, sexism, etc., in the name of overcoming limits or enabling "sustainable development."

The third scenario, that of "Anthropocene park" calls for a return to the ethical and indeed instrumental aim of (environmental) education to protect all biodiversity. This return should recapture both the moral objective of protecting those species that we have collectively deprived 
of their evolutionary future, and the instrumental aim of actually preparing the future generations to face this responsibility for non-human species.

In line with Bonnett (2004, 2007, 2013a), Fien (2000), Kahn (2010) and others, I have argued that there are benefits to re-situating EE and ESD within the broader spirit of education concerned with respect for the natural world as a bearer of intrinsic value. It is not the prescription of a particular outlook which is repugnant to the development of autonomous thinking, but our theoretical and practical inability to critically address the future scenarios and discern what is really at stake that makes the fatalism of Bulgakov's novel so imminent.

Returning to the scenario sketched by Crist (2012, pp. 144-145), we can find hope in humanity's coming to realize [the],

immensity of what we are irretrievably losing, which is not resources but a wonderful abundance of all life. Hope lies in the fact that we are native to the Earth: we have the potential of understanding that we are losing our own family. It is not the imminent danger of reaching the limits-which has been challenged by human ingenuity, it is the danger of losing what we are as people belonging in this world which is at stake.

Considering that I find the Anthropocene park scenario the most plausible (as far as empirical evidence is concerned), renewed support for education for deep ecology and the recognition of intrinsic value of other species seems warranted and urgently needed. The problem is that the notion of democratic processes does not allow enough room for representation of the position of non-humans, as plural perspectives conceive deep ecology merely one of many perspectives. To return to the example of environmental advocacy, the wolves cannot represent themselves; the objective of "educating actively involved citizens" Jickling (2005b, p. 92) does not address those who can only be represented through human advocates.

A different,more affirmative action-oriented education is needed then, similar to that which made an ethical assumption of the value of all human lives and representation of human minority groups so commonplace (at least in Western educational contexts). If the third scenario is most likely, but morally unacceptable, educational practice needs to recognize this, and as the next step, integrate it into its practice and theory, instructed by critical pedagogy. If we view the Anthropocene park scenario with the same moral abhorrence as slavery or other forms of social inequality, EE needs to become much more open in its advocacy. Affirmative action in EE will need to use the example of similar programs used for improving the position of racial and gender minorities, but also needs to be continuous, as non-human species will never be able to speak to us the way human minorities do.

This article is about recognizing that the nature of the catastrophe is the loss of the Earth's biodiversity and the failure of ecological justice, and that it is not sufficiently addressed in education. Ultimately, it is an article against academic debates that seem to be about academic debates - the mirror within the mirror within the mirror. This article is a call for the recognition that despite different scenarios and plural interpretations, to rephrase the environmentalists' lament, while fighting for meaning, we are losing the Earth.

\section{NOTES}

1. To present a balanced position Jickling (2005b) adds that despite the need for neutrality, taking an ethical stance IS important, as it teaches students to be actively involved moral citizens. Jickling asks: "But what if environmental thinking needs to transcend the boundaries of conventional thinking and counter 
more thought-provoking, even radical, ideas? How do we enable our students to push beyond the bounds of our own best thinking, or the conventional wisdom of the day? How do we ensure that they can be exposed to more alternatives?" (p. 93). In interpreting these questions, we can suppose that deep ecology (advocating for the wolves for the sake of wolves) can be considered to be one of those "radical" ideas, and that the "bounds of our own best thinking" imply self-defense against angry parents or intolerant school administrators; and "conventional wisdom of the day" implies an anthropocentric approach to nature. If this interpretation is close to what Jickling meant, then the last question about exposing students to more alternatives remains rather open, as it could mean both the "radical" alternative and any other alternative, which provide no guarantee of non-human rights.

2. Socially critical scholars contest various injustices they argue are inherent in neoliberal discourse and ideology. EE/ESD scholars call for different cultural-historical epistemologies that include more cosmopolitan (Sund \& Öhman 2013) and globally democratic perspectives that expose hegemonic orthodoxies (Jickling \& Wals 2008), rather than education that seeks to marginalize other approaches (Jickling $\&$ Spork 1998). Thus the environmental "problem" instrumentally reconstituted in education is viewed as requiring reconstruction in pursuit of various social and ecological justices.

\section{REFERENCES}

Armstrong, C. D., Foley, N. S., Tinch, R., \& van den Hove, S. (2012). Services from the deep: Steps towards valuation of deep sea goods and services. Ecosystem Services, 2, 3-12.

Baines, K., \& Zarger, R. K. (2012). Circles of value: Integrating Maya environmental knowledge into Belizean schools. In H. Kopnina (Ed.), Anthropology of environmental education. (pp. 65-87). New York, NY: Nova Science Publishers.

Blewitt, J., \& Tilbury, D. (2013). Searching for resilience in sustainable development: Learning journeys in conservation. New York, NY: Routledge.

Bonnett, M. (2004). Retrieving nature. Education for a post-humanist age. Oxford, UK: Blackwell.

Bonnett, M. (2007). Environmental education and the issue of nature. Journal of Curriculum Studies, 39, $707-721$.

Bonnett, M. (2013a). Normalizing catastrophe: Sustainability and scientism. Environmental Education Research, 19, $187-197$.

Bonnett, M. (2013b). Sustainable development, environmental education, and the significance of being in place. Curriculum Journal, 24, 250-271.

Bowers, C. (2002). Toward an eco-justice pedagogy. Environmental Education Research, 8(1), 21-34.

Bulgakov, M. (1996). The master and Margarita. London, UK: Vintage.

Cafaro, P., \& Primack, R. (2014). Species extinction is a great moral wrong. Biological Conservation, 170, 1-2.

Callicott, J. B. (1989). In defense of the land ethic: Essays in environmental philosophy. New York, NY: SUNY Press.

Chawla, L., \& Cushing, D. (2007). Education for strategic environmental behaviour. Environmental Education Research, 13, 437-452.

Cherniak, B. (2012). Critiquing the role of deliberative democracy in EE and ESD: The case for effective participation and pragmatic deliberation. (Master's thesis, Uppsala University, Uppsala, Sweden). Retrieved from http://uu.divaportal.org/smash/get/diva2:543608/FULLTEXT01.pdf

Crist, E. (2012). Abundant earth and population. In P. Cafaro \& E. Crist (Eds), Life on the brink: Environmentalists confront overpopulation (pp. 141-153). Athens, GA: University of Georgia Press.

Daly, H. (1991). Steady state economics. Washington, DC: Island Press.

Desmond, J. (2013). The requiem for a roadkill. In H. Kopnina \& E. Shoreman-Ouimet (Eds.), Environmental anthropology: Future trends (pp. 46-69). New York, NY: Routledge.

Drengson, A. R. (1991). Introduction: Environmental crisis, education, and deep ecology. The Trumpeter, 8(3), 97-98.

Farley, J. (2012). Ecosystem services: The economics debate. Ecosystem Services, 1(1), 40-49.

Fien, J. (2000). Education for the environment: A critique-A response. Environmental Education Research, 6, 179-192.

Foster, J. B. (2002). Ecology against capitalism. New York, NY: Monthly Review Press.

Foster, J. B. (2012). The planetary rift and the new human exemptionalism: A political-economic critique of ecological modernization theory. Organization and Environment, 25, 211-237. 
Goodpaster, K. (1978). On being morally considerable. In M. Zimmerman (Ed.), Environmental philosophy: From animal rights to radical ecology (pp. 49-65). Englewood Cliffs, NJ: Prentice-Hall.

Gough, A. (2006). A long, winding (and rocky) road to Environmental Education for Sustainability in 2006. Australian Journal of Environmental Education, 22(1), 71-76.

Hall, C., \& Day, J. (2009). Revisiting the limits to growth after peak oil. American Scientist, 97, 230-238.

Hart, P. (2005). Transitions in thought and practice: Links, divergences and contradictions in post-critical inquiry. Environmental Education Research, 11, 391-400.

Huckle, J. (1993). Environmental education and sustainability: A view from critical theory. In J. Fien (Ed.), Environmental education: A pathway to sustainability (pp. 43-68). Geelong, Australia: Deakin University.

Huckle, J. (1999). Locating environmental education between modern capitalism and postmodern socialism: A reply to Lucie Sauvé. Canadian Journal of Environmental Education, 4(1), 36-45.

Huckle, J. (2008). Sustainable development. In J. Arthur, I. Davies, \& C. Hahn (Eds.), The Sage handbook of education for citizenship and democracy (pp. 342-354). London, UK: Sage.

Jensen, B. B., \& Schnack, C. (1997). The action competence approach in environmental education. Environmental Education Research, 3, 163-179.

Jickling, B. (1994). Why I don't want my children to be educated for sustainable development: Sustainable belief. The Trumpeter, 11(3). Retrieved from http://trumpeter.athabascau.ca/index.php/trumpet/article/view/325/497

Jickling, B. (2005a). Sustainable development in a globalizing world: A few cautions. Policy Futures in Education, 3, 251-259.

Jickling, B. (2005b). Education and advocacy: A troubling relationship. In E. A. Johnson \& M. Mappin (Eds.), Environmental education and advocacy: Changing perspectives of ecology and education (pp. 91-113). Cambridge, UK: Cambridge University Press.

Jickling, B. (2009). Environmental education research: To what ends? Environmental Education Research, 15, $209-216$.

Jickling, B., \& Spork, H. (1998). Education for the environment: A critique Environmental Education Research, 4, 309-328.

Jickling, B., \& Wals, A. E. J. (2008). Globalization and environmental education: Looking beyond sustainable development. Journal of Curriculum Studies, 40(1), 1-21.

Kahn, R. (2010). Critical pedagogy, ecoliteracy and planetary crisis: The ecopedagogy movement. New York, NY: Peter Lang.

Kareiva, P., Lalasz, R., \& Marvier, M. (2011). Conservation in the Anthropocene: Beyond solitude and fragility. Breakthrough Journal, Fall, 29-37.

Katz, E. (1998). Searching for intrinsic value: Pragmatism and despair in environmental ethics. In A. Light \& E. Katz (Eds.), Environmental pragmatism (pp. 307-318). New York, NY: Routledge.

Kenis, A., \& Mathijs, E. (2012). Beyond individual behaviour change: The role of power, knowledge and strategy in tackling climate change. Environmental Education Research, 18(1), 45-65.

Kopnina, H. (2012a). Education for sustainable development (ESD): The turn away from "environment" in environmental education? Environmental Education Research, 18, 699-717.

Kopnina, H. (2012b). The Lorax Complex: Deep ecology, ecocentrism and exclusion. Journal of Integrative Environmental Sciences, 9, 235-254.

Kopnina, H. (2013a). Evaluating education for sustainable development (ESD): Using ecocentric and anthropocentric attitudes toward the sustainable development (EAATSD) scale. Environment, Development and Sustainability, 15, 607-623.

Kopnina, H. (2013b). Forsaking nature? Contesting "biodiversity" through competing discourses of sustainability. Journal of Education for Sustainable Development, 7(1), 47-59.

Kopnina, H. (2013c). An exploratory case study of dutch children's attitudes towards consumption: Implications for environmental education. The Journal of Environmental Education, 44, 128-144.

Kopnina, H. (2014). Revisiting education for sustainable development (ESD): Examining anthropocentric bias through the transition of environmental education to ESD. Sustainable Development, 22, 73-83.

Kumar, M., \& Kumar, P. (2008). Valuation of the ecosystem services: A psycho-cultural perspective. Ecological Economics, 64, 808-819.

Kronlid, D. O., \& Öhman, J. (2013). An environmental ethical conceptual framework for research on sustainability and environmental education. Environmental Education Research, 19(1), 21-44.

LaChapelle, D. (1991). Educating for deep ecology. Journal of Experiential Education, 14(3), 18-22. 
Læssøe, J., \& Öhman, J. (2010). Learning as democratic action and communication: Framing Danish and Swedish environmental and sustainability education. Environmental Education Research, 16(1), 1-7.

Light, A. (1996). Environmental pragmatism as philosophy or metaphilosophy? In A. Light \& E. Katz (Eds.), Environmental pragmatism (pp. 325-338). New York, NY: Routledge.

Lotz-Sisitka, H. (2004). Positioning southern African environmental education in a changing context. Howick, New Zealand: Share-Net \& Southern African Development Community-Regional Environmental Education Programme.

Marris, E. (2011). Rambunctious garden: Saving nature in a post-wild world. London, UK: Bloomsbury Publishing.

Marvier, A. (2014). A call for ecumenical conservation. Animal Conservation. Retrieved from http://onlinelibrary.wiley.com/doi/10.1111/acv.12130/full

Meadows, D. H., Meadows, D. L., Randers, J., \& Behrens, W. W. III. (1972). The limits to growth. New York, NY: Universe Books.

Merchant, C. (1992). Radical ecology: The search for a liveable world. London, UK: Routledge.

Miller, B., Soulé, M. E., \& Terborgh, J. (2014). "New conservation" or surrender to development? Animal Conservation. doi: $10.1111 /$ acv. 12129

Mol, A. P. J., \& Sonnenfeld, D. A. (2000). Ecological modernisation around the world: Perspectives and critical debates, London, UK: Routledge.

Naess, A. (1973). The shallow and the deep, long-range ecology movement: A summary. Inquiry 16(1), 95-100.

Norton, B. G. (1995). Why I am not a nonanthropocentrist: Callicott and the failure of monisticinherentism. Environmental Ethics, 17, 341-358.

Öhman, J., \& Östman, L. (2008). Clarifying the ethical tendency in education for sustainabledevelopment practice: A Wittgenstein-inspired approach. Canadian Journal of EnvironmentalEducation, 13(1), 57-72.

Orr, D. (1994). Earth in mind: On education, environment, and the human prospect. Washington, DC: Island Press.

Payne, P. (2010). The globally great moral challenge: Ecocentric democracy, values, morals and meaning. Environmental Education Research, 16(1), 153-171.

Portal of Natural Sciences. (2011). Портал Естественньх Наук [Thread "Continuation of argument between Berlioz and Woland"]. Retrieved from http://e-science.ru/forum/index.php?showtopic=34170\&mode= threaded\&pid=315730.

Redford, K. H., \& Adams, W. M. (2009). Payment for ecosystem services and the challenge of saving nature. Conservation Biology, 23, 785-787.

Reed, P., \& Rothenberg, D. (Eds.). (1993). Wisdom in the open air: The Norwegian roots of deep ecology. Minneapolis, MN: University of Minnesota Press.

Robottom, I. (1987). Towards enquiry-based professional development in environmental education. In I. Robottom (Ed.), Environmental education: Practice and possibility. Geelong, Australia: Deakin University Press.

Rolston, H. III (1985). Duties to endangered species. BioScience, 35, 718-726.

Stables, A. (2013). The unsustainability imperative? Problems with "sustainability" and "sustainable development" as regulative ideals. Environmental Education Research, 19, 177-186.

Sund, L., \& Öhman, J. (2013). On the need to repoliticise environmental and sustainability education: Rethinking the postpolitical consensus. Environmental Education Research, epub ahead of print. doi: 10.1080/13504622.2013.833585

Taylor, P. W. (1986). Respect for nature: A theory of environmental ethics. Princeton, NJ: Princeton University Press.

Thompson, K. (2010). Do we need pandas? The uncomfortable truth about biodiversity. Totnes, UK: Green Books.

Van Matre, S. (1978). Sunship Earth. Martinsville, IN: American Camping Association.

Velarde, S. J., Rao, S. H., Evans, K., Vandenbosch, T., \& Prieto, R. (2007, July). Preparing for a changing environment: Using scenarios for environmental education. Paper presented at the 4th World Environmental Education Congress, Durban, South Africa. Abstract retrieved from http://weec2007.com

Wals, A. E. J. (2010). Between knowing what is right and knowing that is it wrong to tell others what is right: On relativism, uncertainty and democracy in environmental and sustainability education. Environmental Education Research, 16(1), 143-151.

Wals, A. E. J. (2012). United Nations decade for sustainable development. DESD monitoring \& evaluation. Paris, France: United Nations Educational, Scientific and Cultural Organization.

Wals, A. E. J., \& Jickling, B. (2002). "Sustainability" in higher education: From doublethink and newspeak to critical thinking and meaningful learning. International Journal of Sustainability in Higher Education, 3, 221232 .

Wells, N., \& Lekies, K. (2006). Nature and the life course. Children, Youth and Environments, 16(1), 1-24. 
Wesselink, R., \& Wals, A. E. J. (2011). Developing competence profiles for educators in environmental education organisations in the Netherlands. Environmental Education Research, 17(1), 69-90.

Wijkman, A., \& Rockström, J. (2012). Bankrupting nature: Denying our planetary boundaries. New York, NY: Routledge.

World Commission on Environment and Development (WCED). (1987). Our common future. Oxford, UK: Oxford University Press.

York, R., \& Rosa, E. A. (2003). Key challenges to ecological modernization theory. Organization and Environment, 16, 273-288.

Zizek, S. (2010). First as tragedy, then as farce. RSA Animate. Retrieved from http://www.youtube.com/watch? $\mathrm{v}=\mathrm{hpAMbpQ8J7g}$ 